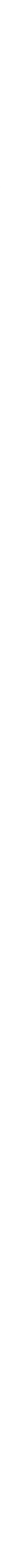

\title{
Oblique map of Loihi seamount and Papa'u landslide, Hawaii
} by Tau Rho Alpha, James M. Morley, Christina E. Gutmacher, and William A. Austin 1982 